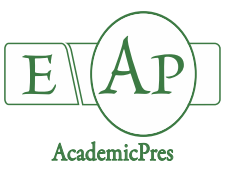

Gutiérrez-Ruelas NJ et al. (2021)

Notulae Botanicae Horti Agrobotanici Cluj-Napoca

Volume 49, Issue 3, Article number 12437

DOI: $10.15835 /$ nbha 49312437

Research Article

\title{
Impact of the foliar application of nanoparticles, sulfate and iron chelate on the growth, yield and nitrogen assimilation in green beans
}

\author{
Nayely J. GUTIÉRREZ-RUELAS ${ }^{1}$, Alejandro PALACIO-MÁRQUEZ, \\ Esteban SÁNCHEZ ${ }^{1 *}$, Ezequiel MUÑOZ-MÁRQUEZ ${ }^{1}$, \\ Celia CHÁVEZ-MENDOZA ${ }^{1}$, Damaris L. OJEDA-BARRIOS ${ }^{2}$, \\ María A. FLORES-CÓRDOVA²
}

\begin{abstract}
${ }^{1}$ Centro de Investigación en Alimentación y Desarrollo A.C., Av. Cuarta Sur No. 3820 Fraccionamiento Vencedores del Desierto, Delicias33089,Chihuahua,México; nayeli.gutierrez.mc18@estudiantes.ciad.mx; alexmarquezmj8@gmail.com; esteban@ciad.mx("correspondingauthor); emunoz@ciad.mx; celia.chavez@ciad.mx

${ }^{2}$ Universidad Autónoma de Chihuahua, Facultad de Ciencias Agrotecnológicas, Carranza y Escorza S/N, Col. Centro, Chihuahua 31000,Chihuahua, México; dojeda@uach.mx;mafloresc@uach.mx
\end{abstract}

\begin{abstract}
Nano-fertilizers (Nfs) have the potential to revolutionize agricultural systems through nanostructures ranging from 1 to $100 \mathrm{~nm}$ that address environmental responses and a more targeted biological demand. The purpose of this work was to study the impact of the foliar application of nanoparticles (NPs), sulfate and iron chelate on the growth, yield and assimilation of nitrogen in green beans. The iron was applied foliar in three different ways: Iron oxide nanoparticles $\left(\mathrm{Fe}_{2} \mathrm{O}_{3}\right)$, ferric sulfate $\left(\mathrm{Fe}_{2}(\mathrm{SO} 4)_{3}\right)$ and iron chelate $(\mathrm{Fe}-\mathrm{EDDHA})$ in doses of 0,25, 50, 100 and $200 \mathrm{ppm}$. The treatments that produced a higher total biomass increase were NPs and Fe-EDDHA at $50 \mathrm{ppm}$, with increases of $37 \%$ and $47 \%$ respectively compared to the control (with no application of $\mathrm{Fe}$ ). Regarding the in vivo nitrate reductase activity, significant differences were obtained, particularly in the NPs and Fe-EDDHA treatment, with increases of $71 \%$ and $72 \%$ respectively. NPs at low doses favored maximum fruit production with increases of $88 \%$ in comparison to the control. Finally, it is concluded that the optimal doses that enhanced total biomass, production and assimilation of nitrogen were $\mathrm{Fe} 2(\mathrm{SO} 4)_{3}$ at $25 \mathrm{ppm}, \mathrm{Fe}-\mathrm{EDDHA}$ at $100 \mathrm{ppm}$ and $\mathrm{Fe}_{2} \mathrm{O}_{3}$ at $25 \mathrm{ppm}$. The efficiency of foliar absorption of iron was found in treatments with $\mathrm{Fe}_{2} \mathrm{O}_{3}$ at 50 and $100 \mathrm{ppm}$. The foliar absorption efficiency of NPs offers sustainable alternatives to increase the productivity of the green bean.
\end{abstract}

Keywords: bean; efficiency; iron; micronutrients; nano-fertilizers; productivity

\section{Introduction}

Nanotechnology is an emerging technology that in recent years has allowed new applications in different areas (Solanki et al., 2015). For agriculture, nano-fertilizers are the most important contribution, as they have the advantage of reducing leaching and in turn improving the nutrient uptake in plants (Liu and Lal, 2015). Nanoparticles (NPs) interact with plants causing many morphological and physiological changes, depending

Received: 14 Jul 2021. Received in revised form: 17 Sep 2021. Accepted: 20 Sep 2021. Published online: 27 Sep 2021.

From Volume 49, Issue 1, 2021, Notulae Botanicae Horti Agrobotanici Cluj-Napoca journal uses article numbers in place of the traditional method of continuous pagination through the volume. The journal will continue to appear quarterly, as before, with four annual numbers. 
on the properties of the NPs (Sidiqui et al., 2015). Their wider use is due to their size (less than $100 \mathrm{~nm}$ ), allowing them an easier penetration through the biological membranes, in comparison with conventional fertilizers (Eichert et al., 2008). Therefore, there is an opportunity to improve the production of several crops through new strategies that offer to use less supplies, reduce production costs and the excessive use of agrochemicals (Servin and White, 2016). In recent years, several studies where these NPs have had positive effects on some crops have been reported. Panwar et al. (2012) found that the application of zinc oxide NPs $(\mathrm{ZnO})$ increased the growth of tomato seedlings at doses of $20 \mathrm{mg} \mathrm{L}^{-1}$, while Rui et al. (2016) had an increased production in peanut crops. The application of these new fertilization strategies to crops like beans (Phaseolus vulgaris $\mathrm{L}$.), which stand out for their high demand for human consumption and are considered a basic food crop, is very important (Suárez-Martínez et al., 2016). Beans are harvested for their dry seeds and immature green pods; they are a good and cheap source of protein (20-28\%). They are rich in minerals such as Fe (70 mg $\left.\mathrm{kg}^{-1}\right)$ and $\mathrm{Zn}\left(33 \mathrm{mg} \mathrm{kg}^{-1}\right)$, and a source of energy (32\%) and fiber (56\%) (Mahajan et al., 2015), so nanoparticles could be an alternative to stimulate their production.

On the other hand, the optimal absorption of micronutrients such as iron $(\mathrm{Fe})$ is important for plant metabolism because it participates in several metabolic and enzymatic processes such as electron transport, nitrogen fixation, hormone and DNA synthesis, among others (Fernandez et al., 2008). Fe is mainly in the form of insoluble $\mathrm{Fe}^{3+}$, especially in high $\mathrm{pH}$ and aerobic soils; therefore, some soils have generally deficiency of the available form, $\mathrm{Fe}^{2+}$ (Ye et al., 2015) problems that the use of conventional fertilizers such as sulfate and iron chelate do not solve because they tend to leach and contaminate the water table (Arizmendi-Galicia et al., 2011). Because of this the application of Fe NPs to crops growing in soils with an alkaline $\mathrm{pH}$ and a high calcium carbonate content is very important, since these problems are common in many crops of agricultural interest. An alternative application of this element is foliar fertilization, which has a quick absorption through the leaf epidermis, and which is accessible to other parts of the plant via the xylem and phloem (Nasiri et al., 2010). It also has a more immediate and targeted response than soil fertilization, since the nutrients can be applied during the critical stages of plant growth (Fernandez et al., 2015) and the nutrients are properly used by reducing environmental pollution because of the lower amount of fertilizers that are added to the soil. However, despite the fact that there are numerous studies of nanoparticles in agriculture, there are still few reports on the use of NP as fertilizers and its performance in comparison with traditional fertilizers as there are several aspects that have not yet been explored in detail. Thus, the purpose of this work was to study the impact of the foliar application of nanoparticles, sulfate and iron chelate on the growth, yield and assimilation of nitrogen in green beans cv. 'Strike'.

\section{Materials and Methods}

\section{Crop management}

The experiment was carried out in the facilities of the Center for Research in Food and Development in Delicias, Chihuahua, México, during the month of April and May 2019. The experiment was carried out under greenhouse conditions at an average environmental temperature of $32.48^{\circ} \mathrm{C}$, with a minimum temperature of $25.16^{\circ} \mathrm{C}$ and a maximum of $39.8^{\circ} \mathrm{C}$, solar radiation of $6.9 \mathrm{kWhm}^{-2}$ and relative humidity of $60 \%$. Green beans ( $P$. vulgaris L. cv. 'Strike') seeds were sown directly in plastic pots of $13.4 \mathrm{~L}$ volume and with a substrate weight per pot of $2.907 \mathrm{~kg}$ (two plants per pot) in a mixture of perlite and vermiculite substrate at a ratio of $1: 2$. The plants were watered with a complete nutrient solution consisting of $6 \mathrm{mM}^{\circ} \mathrm{NH}_{4} \mathrm{NO}_{3}, 1.6 \mathrm{mM}$ of $\mathrm{K}_{2} \mathrm{HPO}_{4}$, $0.3 \mathrm{mM}$ of $\mathrm{K}_{2} \mathrm{SO}_{4}, 4.0 \mathrm{mM}$ of $\mathrm{CaCl}_{2} \bullet 2 \mathrm{H}_{2} \mathrm{O} 1.4 \mathrm{mM}$ of $\mathrm{MgSO}_{4} \bullet 7 \mathrm{H}_{2} \mathrm{O}, 2 \mu \mathrm{M}$ of $\mathrm{MnSO}_{4} \bullet \mathrm{H}_{2} \mathrm{O}, 1.0 \mu \mathrm{M}$ of $\mathrm{ZnSO}_{4} \bullet 7 \mathrm{H}_{2} \mathrm{O}, 0.25 \mu \mathrm{M}$ of $\mathrm{CuSO}_{4} \bullet 5 \mathrm{H}_{2} \mathrm{O}, 0.3 \mu \mathrm{M}$ of $\left(\mathrm{NH}_{4}\right) 6 \mathrm{Mo}_{7} \mathrm{O}_{24} \bullet 4 \mathrm{H}_{2} \mathrm{O}$, and $0.5 \mu \mathrm{M}$ of $\mathrm{H}_{3} \mathrm{BO}_{3}$, which was developed using distilled water at $\mathrm{pH} 6.0-6.1$ and $\mathrm{EC}$ of $1.289 \mathrm{dS} \mathrm{m}^{-1}$. The solution was applied up to the field capacity of the substrate every third day. The iron-based treatments were applied by foliar spraying. The 
foliar application of the treatments was carried out from the appearance of the first true leaves ( 15 days after germination), every 10 days for a total of 5 applications during the crop cycle.

\section{Experimental design and treatments}

A completely randomized experimental design with four repeated doses per treatment was used. The sources of iron were the following: Ferric sulfate $\left(\mathrm{Fe}_{2}\left(\mathrm{SO}_{4}\right)_{3}\right)$, iron chelate (Fe-EDDHA) and iron oxide nanoparticles $\left(\mathrm{Fe}_{2} \mathrm{O}_{3}\right)$ applied in a foliar way in doses of 0,25, 50, 100 and $200 \mathrm{ppm}$ (Table 1).

Table 1. Treatment description (doses and sources of application)

\begin{tabular}{|l|c|c|}
\hline \multicolumn{1}{|c|}{ Fe Source } & Dose (ppm) & Code \\
\hline Control & 0 & Control \\
\hline Sulfate $\left(\mathrm{Fe}_{2}\left[\mathrm{SO}_{4}\right]_{3}\right)$ & 25 & S25 \\
\hline Sulfate $\left(\mathrm{Fe}_{2}\left[\mathrm{SO}_{4}\right]_{3}\right)$ & 50 & S50 \\
\hline Sulfate $\left(\mathrm{Fe}_{2}\left[\mathrm{SO}_{4}\right]_{3}\right)$ & 100 & S100 \\
\hline Sulfate $\left(\mathrm{Fe}_{2}\left[\mathrm{SO}_{4}\right]_{3}\right)$ & 200 & S200 \\
\hline Chelate $(\mathrm{Fe}-\mathrm{EDDHA})$ & 25 & $\mathrm{C} 25$ \\
\hline Chelate $(\mathrm{Fe}-\mathrm{EDDHA})$ & 50 & $\mathrm{C} 50$ \\
\hline Chelate $(\mathrm{Fe}-\mathrm{EDDHA})$ & 100 & C100 \\
\hline Chelate $(\mathrm{Fe}-\mathrm{EDDHA})$ & 200 & C200 \\
\hline $\mathrm{NPs}\left(\mathrm{Fe}_{2} \mathrm{O}_{3}\right)$ & 25 & NPs-Fe25 \\
\hline $\mathrm{NPs}\left(\mathrm{Fe}_{2} \mathrm{O}_{3}\right)$ & 50 & NPs-Fe50 \\
\hline $\mathrm{NPs}\left(\mathrm{Fe}_{2} \mathrm{O}_{3}\right)$ & 100 & NPs-Fe100 \\
\hline $\mathrm{NPs}\left(\mathrm{Fe}_{2} \mathrm{O}_{3}\right)$ & 200 & NPs-Fe200 \\
\hline
\end{tabular}

\section{Nano-fertilizer characterization}

In this study the nano-fertilizer used was iron oxide $\left(\mathrm{Fe}_{2} \mathrm{O}_{3}\right)$ obtained by wet chemistry methods in the form of magnetic and semiconductor nanoparticles of iron oxide (maghemite $\left.\left(\gamma-\mathrm{Fe}_{3} \mathrm{O}_{3}\right)\right)$. The shape and size were determined by Scanning Electron Microscopy (SEM) (Figure 1) and Transmission Electron Microscopy (TEM) (Figure 2). According to the information provided by the manufacturer, the nanoparticles have an average size of less than $50 \mathrm{~nm}$ and a purity level of $99.7 \%$ (Figure 3). The nanoparticles were obtained from the Mexican company Investigación y Desarrollo de Nanomateriales S.A. de C.V.
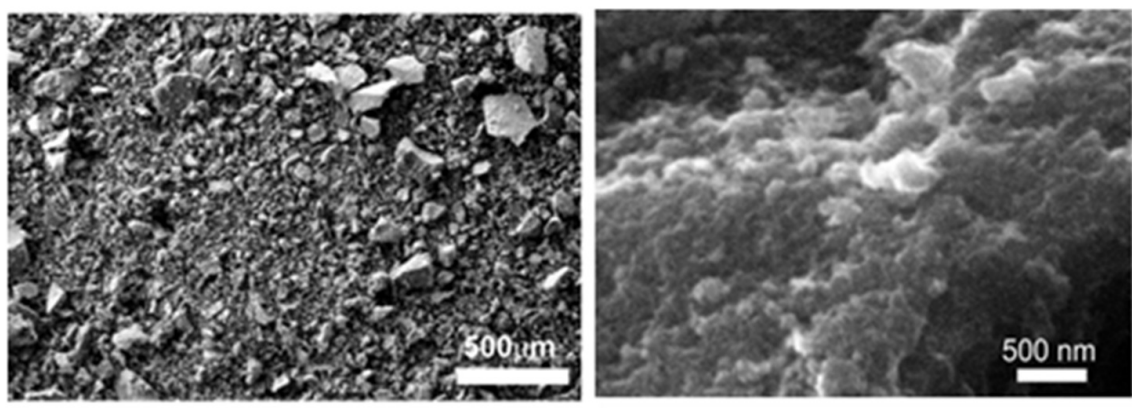

Figure 1. Sample morphology using Scanning Electron Microscopy (SEM) 

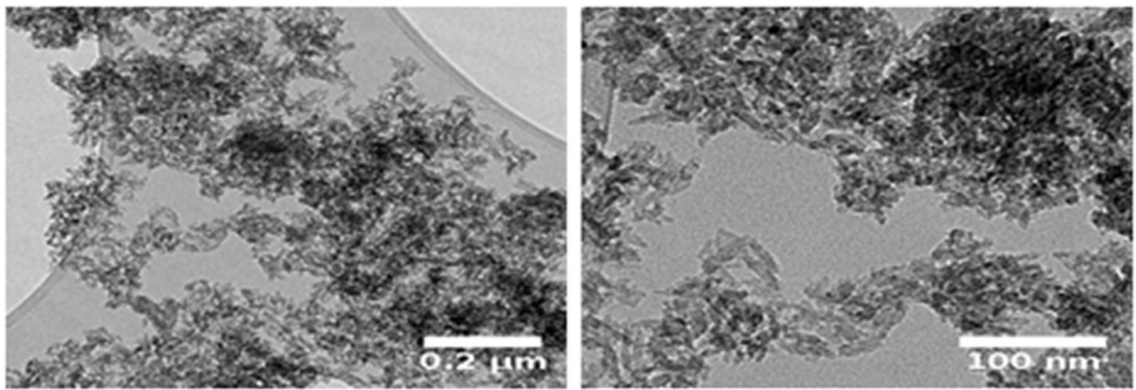

Figure 2. Sample morphology using Transmission Electron Microscopy (TEM)

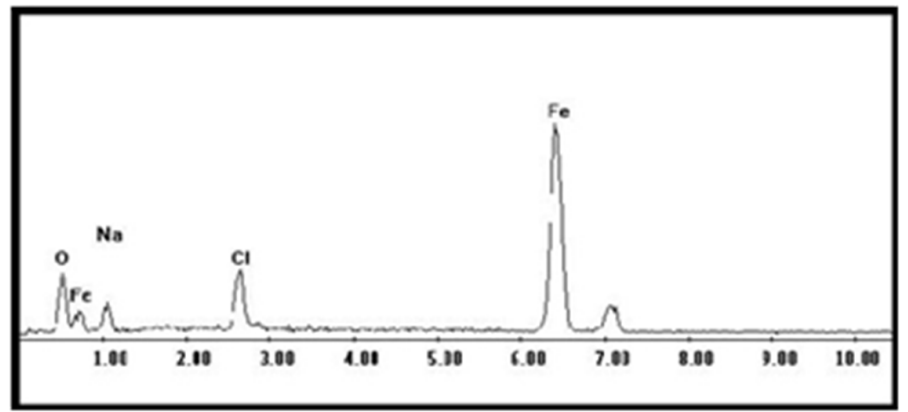

Figure 3. Elemental analysis (chemical characterisation) using Energy-dispersive X-ray spectroscopy (EDX)

\section{Plant sampling}

The plants were sampled at 60 days after sowing, at full pod development. All the leaf samples were taken in the mature state. At the time of sampling, the fresh material was used to quantify biomass, fruit production, nitrate reductase (NR) activity in vivo (EC 1.6.6.1) and quantification of photosynthetic pigments. Part of the fresh material was dried in an oven, and later it was used to determine the iron content of the leaves. Four repetitions per treatment were used for each variable analysed.

\section{Plant analysis}

\section{$\underline{\text { Biomass }}$} (gd.w.).

The production of foliar biomass was obtained from the average weight per plant based on dry matter

Yield

The yield of the plant was expressed as the average weight of the fruits per plant and expressed in grams of fresh weight ( $\mathrm{g}$ f.w).

\section{Assay of the enzymatic activity of nitrate reductase (EC 1.6.6.1)}

In a reduction process, the enzyme nitrate reductase transforms nitrates $\left(\mathrm{NO}_{3}{ }^{-}\right)$into nitrites $\left(\mathrm{NO}_{2}{ }^{-}\right)$. To quantify it, the method proposed by Sánchez et al. (2004) was used. The leaves were cut into cylindrical sections of $5 \mathrm{~mm}$ in diameter and the sample was placed in $10 \mathrm{ml}$ of incubation buffer $(10 \mathrm{mM}$ of $100 \mathrm{mM}$ potassium phosphate buffer, $\mathrm{pH} 7.5)$ and $1 \%(\mathrm{v} / \mathrm{v})$ of propanol. The samples were infiltrated, and the intracellular spaces of the tissues were washed with buffer using a vacuum $(0.08 \mathrm{MPa})$. After five minutes, the vacuum was released, and the samples were re-evacuated; They were incubated at $30{ }^{\circ} \mathrm{C}$ in the dark for one hour and then placed in boiling water to interrupt Nitrate Reductase (NR) activity. $\mathrm{NO}_{2}^{-}$were determined by spectrophotometry at $540 \mathrm{~nm}$ in a reaction mixture consisting of $2 \mathrm{~cm}^{3}$ of extract, $2 \mathrm{~cm}^{3}$ of $1 \%$ sulfanilamide $(\mathrm{m} / \mathrm{v})$ in $1.5 \mathrm{M} \mathrm{HCl}$ and 
$2 \mathrm{~cm}^{3} 0.02 \%(\mathrm{~m} / \mathrm{v}) \mathrm{N}-\left(1-\mathrm{Naphthyl}\right.$ dihydrochloride)-ethylenediamine in $0.2 \mathrm{M} \mathrm{HCl}\left(\mathrm{NR}+\mathrm{NO}_{3}{ }^{-}\right)$, following the same method but using a modified incubation buffer containing $50 \mathrm{mM} \mathrm{KNO}_{3}$. The $\mathrm{NR}$ induced by $\mathrm{NO}_{3}{ }^{-}$ and $\mathrm{Mo}\left(\mathrm{NR}+\mathrm{NO}_{3}{ }^{-}+\mathrm{Mo}\right)$, and the $\mathrm{NR}$ induced by $\mathrm{NO}_{3}{ }^{-}$and $\mathrm{Mo}\left(\mathrm{NR}+\mathrm{NO}_{3}^{-}+\mathrm{Mo}\right)$, were also determined using a modification of the incubation buffer containing $20 \mathrm{mM} \mathrm{NaMoO}_{4}$ and $\mathrm{KNO}_{3}$ plus $50 \mathrm{mM} \mathrm{NaMoO}_{4}$ $20 \mathrm{mM}$, respectively. The resulting nitrate concentration was also determined spectrophotometrically.

\section{Photosynthetic pigments}

The method used for the extraction and quantification of pigments from the leaf was the method described by Wellburn (1994). The total chlorophyll concentration was quantified by extraction with methanol and absorbance measurement. Foliar discs of $7 \mathrm{~mm}$ in diameter corresponding to $0.15 \mathrm{~g}$ of fresh plant material (leaves) were weighed and placed in test tubes with $10 \mathrm{~mL}$ of pure methanol $\left(\mathrm{CH}_{3} \mathrm{OH}\right)$. The tubes were stored at room temperature, in the dark and for $24 \mathrm{~h}$. Subsequently, the absorbance was measured at 653 $\mathrm{nm}$ (chlorophyll b, chl b) and $666 \mathrm{~nm}$ (chlorophyll a, chl a). The total content of chlorophyll was expressed in $\mathrm{mg} \mathrm{g}^{-1}$ of fresh weight (f.w.). The content of foliar pigment was estimated using the following equations:

Chlorophyll a: $\left(15.65^{*} \mathrm{~A} 666\right)-\left(7.34^{*} \mathrm{~A} 653\right)$

Chlorophyll b: $\left(27.05^{*} \mathrm{~A} 653\right)-\left(11.21^{*} \mathrm{~A} 666\right)$

\section{Determination of iron content}

Fe concentration was determined by an Inductive Couple Plasma Optical Emission Spectrometer (Agilent Technologies 700 Series ICP-OES, California, USA), according to the method described by Karacan and Aslantas (2008). Fe concentration was expressed in $\mathrm{mg} \mathrm{kg}^{-1}$ of dry weight.

\section{Quantification of amino acids and proteins}

The amino acids and proteins were determined after homogenization of $0.5 \mathrm{~g}$ fresh samples in $50 \mathrm{mM}$ cold $\mathrm{KH}_{2} \mathrm{PO}_{4}$ buffer at $\mathrm{pH} 7$ and centrifugation at $12000 \mathrm{x}$ for $15 \mathrm{~min}$. The resulting supernatant was used for the determination of total amino acids by the ninhydrin method (Yemm et al., 1955). Total free amino acids were expressed as $\mathrm{mg}$ glycine $\mathrm{g}^{-1}$ fresh weight $(\mathrm{FW})$. Soluble protein was measured with Bradford G-250 reagent (Bradford, 1976) and expressed as $\mathrm{mg} \mathrm{g}^{-1} \mathrm{FW}$, using bovine serum albumin (BSA) as standard.

\section{Statistical analysis}

The data obtained were subjected to analysis of variance. To determine differences between means of the treatments, the LSD test was used at 95\%, using a statistical software called SAS 8 (SAS Inst. Inc. Cary, $\mathrm{NC})$. The data shown are mean values \pm standard error (s.e.). The levels of significance were represented by * $\mathrm{P}<0.05,{ }^{* *}$ at $\mathrm{P}<0.01,{ }^{* * *} \mathrm{P}<0.001$ and $\mathrm{NS}$, not significant.

\section{Results and Discussion}

\section{Biomass and yield}

The increase in biomass is one of the essential parameters for determining nutrient efficiency in crops (Szarka et al., 2012). The present study showed that the highest accumulation of biomass was found in the chelate treatments at a dose of $50 \mathrm{ppm}$, followed by NPs-Fe 50 and S25 which had an increase of 46\%, 35\% and $31 \%$ respectively, in comparison to the control in which no application was used (Figure 4). These results are consistent with those reported by Riu et al. (2016), who did not obtain significant differences in biomass accumulation between iron oxide NPs $\left(\mathrm{Fe}_{2} \mathrm{O}_{3}\right)$ and iron chelate (Fe-EDTA) treatments in peanut crops. Doses above $50 \mathrm{ppm}$ for NPs-Fe and chelate could be considered high or toxic for the plant because above these doses the total biomass accumulation decreases. Previous studies revealed that the exposure of plants to nanoparticles 
can alter the nutrient uptake and lead to several biological activities, causing variations in growth and yield in different plant species (Kanwar et al., 2019).

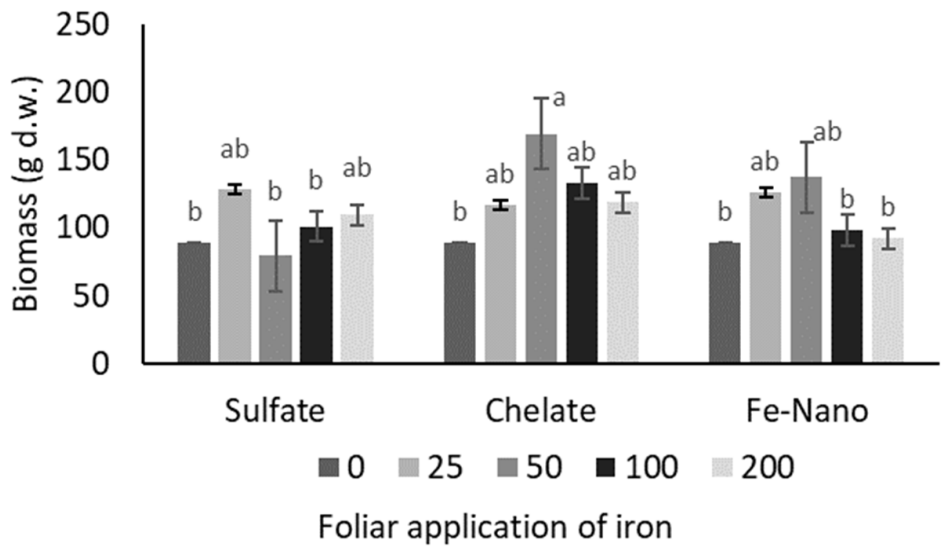

Figure 4. Effect of foliar application of ferric sulfate $\left(\mathrm{Fe}_{2}\left(\mathrm{SO}_{4}\right)_{3}\right)$, iron oxide nanoparticles $\left(\mathrm{Fe}_{2} \mathrm{O}_{3}\right)$ and iron chelate (EDDHA) on the total biomass of green beans cv. 'Strike'

Data are means \pm s.e. Different letters show statistically significant differences

Other important agronomic parameters are the production, where the biological yield of the crops can be observed (Rawat et al., 2017). In the present study, Fe-Nano treatment at a dose of $25 \mathrm{ppm}$ favored maximum fruit production with significant increases of $88 \%$ in comparison to the control where no application was used. The S100 and C100 treatments had the highest increase ( $81 \%$ and $77 \%)$ respectively, in comparison to the control (Figure 5). Previous studies reported by Sheykhbaglou et al. (2010), showed a $48 \%$ increase over the control treatment, when iron nanoparticles were applied to the soybean yield. On the other hand, Drostkar et al. (2016), also reported positive results for foliar application of iron oxide nanoparticles $\left(\mathrm{Fe}_{2} \mathrm{O}_{3}\right)$ with a 47 $\%$ increase in chickpea crops, compared to the control. This could be due to the quick release of soluble iron ions from the nanoparticles, characterized by their small size and large surface area (Kandpal et al., 2014). This results in higher physiological traits that may be toxic or beneficial to some crops - such as increased yield compared to chelate and sulfate sources.

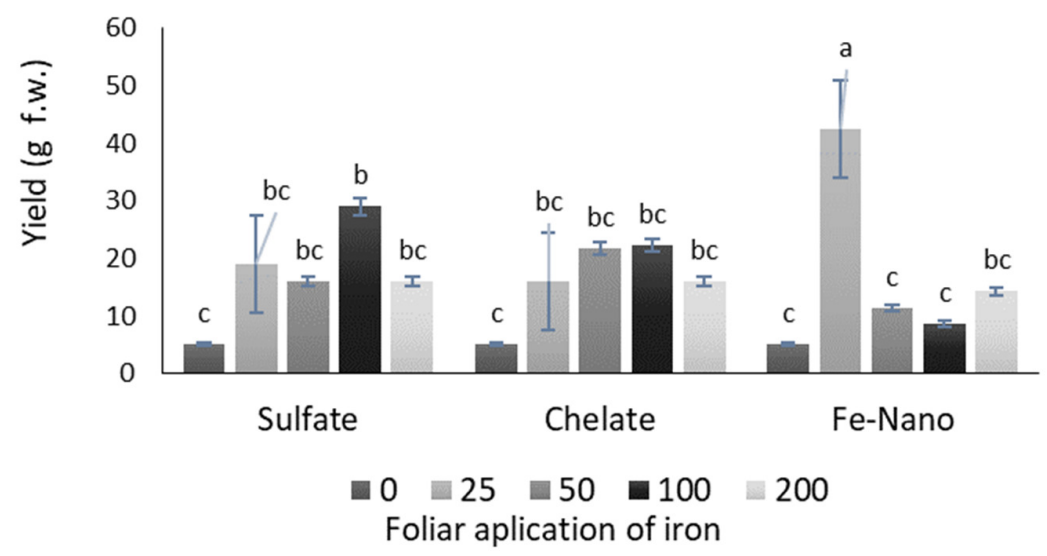

Figure 5. Effect of foliar application of ferric sulfate $\left(\mathrm{Fe}_{2}\left(\mathrm{SO}_{4}\right)_{3}\right)$, iron oxide nanoparticles $\left(\mathrm{Fe}_{2} \mathrm{O}_{3}\right)$ and iron chelate (EDDHA) on the yield of green beans cv. 'Strike'

Data are means \pm s.e. Different letters show statistically significant differences. 


\section{Nitrogen assimilation}

Nitrate reductase (NR, EC 1.6.6.1) is the key enzyme, responsible for the reduction of nitrate to nitrite as a first step in the plant's nitrogen assimilation (Yaneva et al., 2000). Nitrogen is an essential element for plant growth and development, needed to carry out a variety of processes and it is the main constituent of amino acids and proteins. In the present study, we can observe significant differences in the enzymatic activity of the NPs-Fe100 and C200 treatments with increases of $71 \%$ and $72 \%$ respectively compared to the control. While with sulfates there were no significant differences between the treatments and the control (Figure 6a). If the results of Figures 4 and 5 are considered, this increase in NR activity does not seem to be related to the increase in biomass and yield. Nevertheless, when adding a substrate (in this case nitrates) it was observed that the activity of the enzyme increased in comparison to the treatments where no nitrates were added (Figure 6a and $6 \mathrm{~b})$, it was probably due to the fact that it physiologically lacked this nutrient, which functions as a substrate to activate the NR enzyme. These increases in the treatments also correspond to the doses with the highest accumulation of biomass (Figure 4). Therefore, high NR activity in plant material indicates higher efficiency in reducing nitrogen to the aminic forms within the plant material so that it can be used for growth and development. This is consistent with what has been reported by several authors who conclude that proper nitrogen assimilation is shown to be reflected in biomass production (Sánchez et al., 2006).
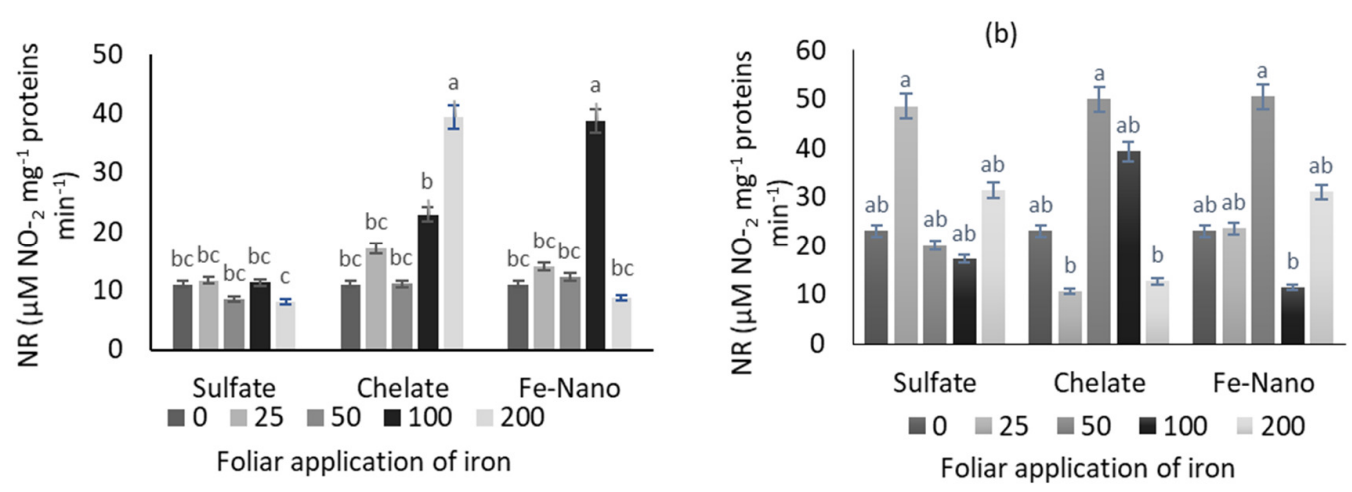

Figure 6. Effect of foliar application of ferric sulfate $\left(\mathrm{Fe}_{2}\left(\mathrm{SO}_{4}\right)_{3}\right)$, iron oxide nanoparticles $\left(\mathrm{Fe}_{2} \mathrm{O}_{3}\right)$ and iron chelate (Fe-EDDHA) regarding the endogenous (a) and induced with $\mathrm{NO}_{3}{ }^{-}$(b) $\mathrm{NR}^{2}$ activity Data are means \pm s.e. Different letters show statistically significant differences.

\section{Content of photosynthetic pigments}

Photosynthesis is a very important process in which plants convert the energy of sunlight into chemical energy to grow and develop (Kanwar et al., 2019). Iron is a structural component of several porphyrin ring molecules, such as cytochromes, hemes, ferricromes, and leghemoglobin (Askary et al., 2016). Most Fecontaining enzymes are involved in oxidation-reduction reactions in respiration and photosynthesis (Mohammad et al., 2013). In the present study, the total chlorophyll content in bean leaves was similar for most of the assessed treatments. The highest increases were $18 \%$ for C100, 17\% for S25 and 6\% in NPs-Fe 50 in comparison to the control where no application was used (Figure 7). In the case of NPs, this increase was similar to treatment with a higher accumulation of total biomass (Figure 4), which could be related to the fact that at this dose there is a better assimilation of iron, since it is a co-factor of many enzymes that accelerate the growth and development processes of plants (Feizi et al., 2013). On the other hand, in Figure 7 it can also be observed that the lowest concentration of chlorophylls was for NPs-Fe25 treatment; however, this could be due to the fact that at this dose the plant reached its physiological maturity faster compared to the other treatments and therefore started to decrease the concentration of pigments in the leaves to translocate nutrients to the fruit, given that this treatment reached the maximum fruit production compared to the control (Figure $5)$. 


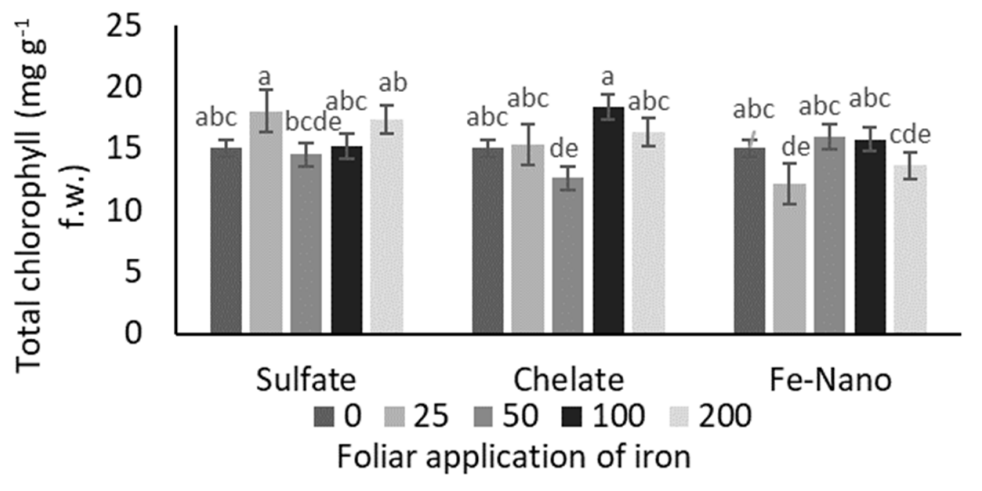

Figure 7. Concentration of photosynthetic pigments as a result of the foliar application of ferric sulfate $\left(\mathrm{Fe}_{2}\left(\mathrm{SO}_{4}\right)_{3}\right)$, iron oxide nanoparticles $\left(\mathrm{Fe}_{2} \mathrm{O}_{3}\right)$ and iron chelate ( $\left.\mathrm{Fe}-\mathrm{EDDHA}\right)$ in green beans

Data are means \pm s.e. Different letters show statistically significant differences.

\section{Aminoacids and proteins}

The main products of nitrogen assimilation in plants are mainly amino acids and proteins (Sánchez et al., 2004). In the present study, we can observe that the foliar application of iron nanoparticles had increases in the amino acids content in the C25 and NPs-Fe100 treatments, with increases of $27 \%$ and $19 \%$ respectively compared to the control. In the same way that proteins, sulfate treatments did not have significant differences between treatments and control (Table 2). In this case, nanoparticles were less favored compared to chelates at low doses, this could be due to the increase in soluble protein content (Table 2) where the highest protein concentration was found in the NPs-Fe50 treatment. Previously, Rui et al. (2018) reported a decrease in the amino acids content in peanuts treated with iron oxide $\left(\mathrm{Fe}_{2} \mathrm{O}_{3}\right)$ compared to the control. Amino acids concentration can also be influenced by NR activity in plant material, since nitrogen is one of the main components of amino acids and proteins, fundamental components for the growth and development of plants (Sánchez et al., 2006). In the case of nanoparticles, the highest concentration of $100 \mathrm{ppm}$ also corresponds to the highest activity of the NR enzyme (Figure 6a). So, it is important to optimize the doses in different crops since amino acids are one of the main indicators to assess the nutrition and quality of the crops (Zhang et al., 2016).

Table 2. Effect of foliar application of ferric sulfate $\left(\mathrm{Fe}_{2}\left(\mathrm{SO}_{4}\right)_{3}\right)$, iron oxide nanoparticles $\left(\mathrm{Fe}_{2} \mathrm{O}_{3}\right)$ and iron chelate (EDDHA) on the concentration of amino acids in leaves of green bean plants

\begin{tabular}{|l|c|c|c|}
\hline Fe Dose (ppm) & \multicolumn{2}{|c|}{ Concentration of amino acids $\mathbf{~ m g ~ g ~}^{-1}$ f.w.) } \\
\hline 0 & Sulfate & Chelate & Fe-Nano \\
\hline 25 & $2.61 \mathrm{~cd}$ & $2.61 \mathrm{~cd}$ & $2.61 \mathrm{~cd}$ \\
\hline 50 & $2.52 \mathrm{~d}$ & $3.58 \mathrm{a}$ & $2.45 \mathrm{~d}$ \\
\hline 100 & $2.95 \mathrm{abcd}$ & $2.58 \mathrm{~cd}$ & $2.82 \mathrm{bcd}$ \\
\hline 200 & $2.87 \mathrm{bcd}$ & $2.72 \mathrm{~cd}$ & $3.24 \mathrm{abc}$ \\
\hline
\end{tabular}

Data are means \pm s.e. Different letters show statistically significant differences.

Regarding protein concentration, the foliar application of NPs-Fe50 and C200 had significant increases of $24 \%$ and $20 \%$ in protein content compared to the control. While with sulfates there were no significant differences between treatments and control (Table 3). Similar results were reported in a study carried out by Wang et al. (2016), where the soluble protein content in watermelon leaves treated with $\gamma-\mathrm{Fe}_{2} \mathrm{O}_{3}$ at $50 \mathrm{mg} \mathrm{L} \mathrm{g}^{-1}$ increased by $24.8 \%$ in the fourth week, compared to the control. So, we can assume that these nanoparticles work better at low doses and that, as with biomass, the use of high doses generates a lower protein concentration 
than the control without application. Previous studies have reported that high doses of Fe nanoparticles generate an excess of reactive oxygen species, which can affect amino acids, fragment peptide chains and consequently have a greater susceptibility to proteolysis. (Sharma et al., 2012).

Table 3. Effect of foliar application of ferric sulfate $\left(\mathrm{Fe}_{2}\left(\mathrm{SO}_{4}\right)_{3}\right)$, iron oxide nanoparticles $\left(\mathrm{Fe}_{2} \mathrm{O}_{3}\right)$ and iron chelate (EDDHA) on the concentration of proteins in leaves of green bean plants. Data are means \pm s.e. Different letters show statistically significant differences.

\begin{tabular}{|l|c|c|c|}
\hline \multirow{2}{*}{ Fe Dose (ppm) } & \multicolumn{3}{|c|}{ Concentration of proteins $\left(\mathbf{m g ~ g}^{-1}\right.$ f.w.) } \\
\cline { 2 - 4 } & Sulfate & Chelate & Fe-Nano \\
\hline 0 & $6.02 \mathrm{~cd}$ & $6.02 \mathrm{~cd}$ & $6.02 \mathrm{~cd}$ \\
\hline 25 & $6.19 \mathrm{bcd}$ & $7.52 \mathrm{abc}$ & $5.94 \mathrm{~cd}$ \\
\hline 50 & $6.98 \mathrm{abcd}$ & $6.46 \mathrm{abcd}$ & $7.91 \mathrm{a}$ \\
\hline 100 & $6.99 \mathrm{abcd}$ & $7.19 \mathrm{abcd}$ & $7.20 \mathrm{abcd}$ \\
\hline 200 & $7.50 \mathrm{abc}$ & $7.68 \mathrm{ab}$ & $5.73 \mathrm{~d}$ \\
\hline
\end{tabular}

\section{Iron content}

Micronutrients such as Fe play an important role in plant metabolism. Fe is one of the structural elements of organic components because it is a co-factor in many enzymatic reactions and it is also present in the proteins that participate mainly in photosynthesis, nitrogen and sulfur assimilation (Van Hoewyk et al., 2007). In the present study, the highest concentrations of iron content in leaves were obtained for the S100, C200 and NPs-Fe50 treatments with increases of $19 \%, 7 \%$ and $11 \%$ respectively in relation to the control (Figure 8). In the case of the NPs treatment, the highest increase in iron content compared to the control was at its dose of $50 \mathrm{ppm}$, which also corresponds to the greater accumulation of biomass. On the other hand, the high dose of this treatment presented the lowest Fe concentration, and, at the same time, it presented a lower biomass accumulation (Figure 4), which could indicate that at high doses the Fe is not efficiently supplied to other parts of the plant, causing a possible toxicity. High Fe levels can cause a variety of effects in plants such as delayed root and shoot growth, altered photosynthesis and decreased chlorophyll concentration (Ravet et al., 2009).

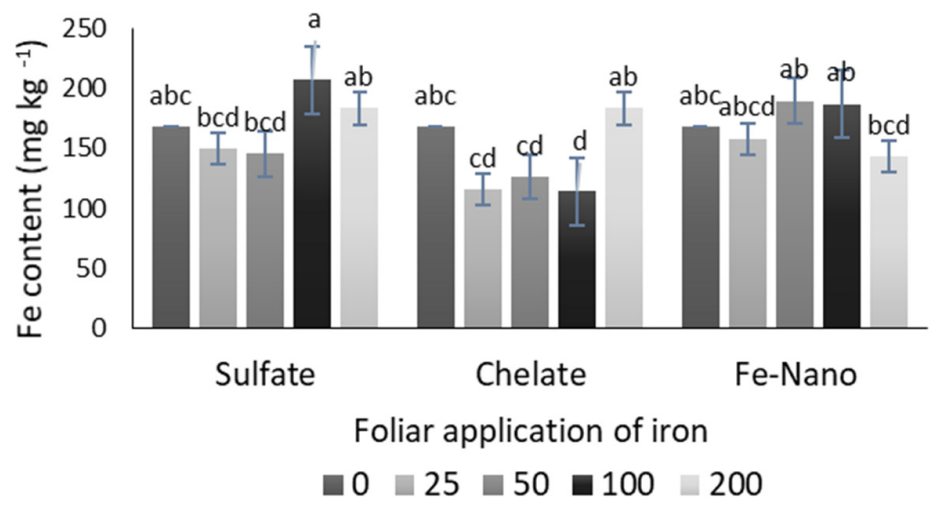

Figure 8. Iron mineral content in leaves as a result of the foliar application of ferric sulfate $\left(\mathrm{Fe}_{2}\left(\mathrm{SO}_{4}\right)_{3}\right)$, iron oxide nanoparticles $\left(\mathrm{Fe}_{2} \mathrm{O}_{3}\right)$ and iron chelate (Fe-EDDHA) in green beans Data are means \pm s.e. Different letters show statistically significant differences.

Based on these results, it is postulated that the main growth indicators such as biomass and yield were favorable for low-dose nanoparticles. Other treatments such as S100 and C200 also showed positive results as mentioned above; nevertheless, even if the sulfates responded favorably in some cases with low doses, this dose 
did not encourage fruit production which would imply an increase in the dose to increase production (Figure 5). Meanwhile, the chelates responded proficiently to the NPs, but mostly at high doses. In the same way, SidaArreola et al. (2015), found that high doses of chelate had a higher concentration of Fe in bean fruits, obtaining increases of 8 and $28 \%$ in relation to the control without application. Also, Ghafari and Razmjoo (2013), found increases in Fe content when applying doses of $8 \mathrm{~g} . \mathrm{L}^{-1}$ chelate in wheat plants. These results together with those obtained in the present research work allow us to suppose that to obtain high concentrations of Fe in plant tissues it is necessary to apply doses above $100 \mathrm{ppm}$ of chelate, however, more research must still be done in this regard.

Therefore, with iron oxide NPs a higher yield was achieved using smaller doses, demonstrating that the nanoparticles have positive effects at right doses in green bean plants. On the other hand, the plants exposed to NPs, also they had accelerated effects in the physiological maturation (data not shown), since the plants treated with NPs managed to mature in less time using the lower dose, also achieving a larger production of fruits, in comparison with the other treatments. It is known that these nanoparticles provide a more soluble form of these elements due to their high reactivity, so they are somewhat more effective (Zia-ur-Rehman et al., 2018). Nevertheless, crops may respond differently as they are not only subjected to the effects of these NPs but also to external factors.

\section{Conclusions}

The optimal doses that enhanced total biomass, yield and assimilation of nitrogen were S25, C100 and NPs-Fe25. The efficiency of foliar absorption of iron was found in treatments with NPs-Fe50 and NPs-Fe100. NPs can have a great potential as nano-fertilizers if they are applied in optimal concentrations and in the stages of highest demand of each crop, since it is evident that the effect of NPs varies from one plant to another and depends on the application method, size and concentration. Finally, it is worth mentioning that more research is needed to explore the whole action scope of NPs, namely their interaction with biomolecules, their impact and their effect against external factors that influence plant growth.

\section{Authors' Contributions}

E.S and N.J.G-R designed the study. C.C.-M. and A.P.-M. analyzed the data. E.S. and N.J.G.-R. prepared the manuscript, while E.M.-M., C.C.-M., D.L.O.-B., and M.A.F.-C. conducted the experiments. A.P.-M., N.J.G.-R. and E.S. organized the data and performed the statistical analysis. All authors read and approved the final manuscript.

\section{Acknowledgements}

We would like to thank the Consejo Nacional de Ciencia y Tecnología (CONACyT-Mexico) for the support provided by means of the Convocatoria Atención a Problemas Nacionales: Project \#1529

"Biofortification of basic agricultural crops representing the key to combat malnutrition and ensure food security in Mexico". In addition, we thank the company "Investigación y Desarrollo de Nanomateriales S.A de C.V." for the donation of iron oxide nanoparticles $\left(\mathrm{Fe}_{2} \mathrm{O}_{3}-50 \mathrm{~nm}\right)$, and by a grant from the Consejo Nacional de Ciencia y Tecnología (CONACYT), Government of Mexico awarded to Nayely Jazmín Gutiérrez-Ruelas (CVU 916330) to do Master of Science studies. 


\section{Conflict of Interests}

The authors declare that there are no conflicts of interest related to this article.

\section{References}

Arizmendi-Galicia N, Rivera-Ortiz P, Cruz-Salazar FDL, Castro-Meza BI, Garza-Requena FDL (2011). Lixiviación de hierro quelatado en suelos calcáreos [Leaching of chelated iron in calcareous soils]. Terra Latinoamericana 29(3):231-237. http://www.scielo.org. $\mathrm{mx} /$ scielo.php?script=sci_arttext\&pid=S0187-57792011000300231

Askary M, Amirjani MR, Saberi T (2017). Comparison of the effects of nano-iron fertilizer with iron-chelate on growth parameters and some biochemical properties of Catharanthus roseus. Journal of Plant Nutrition 40(7):974-982. https://doi.org/10.1080/01904167.2016.1262399

Bradford MM (1976). A rapid and sensitive method for the quantitation of microgram quantities of protein utilizing the principle of protein-dye binding. Analytical Biochemistry 72(1-2):248-254. https://doi.org/10.1016/00032697(76)90527-3

Drostkar E, Talebi R, Kanouni H (2016). Foliar application of Fe, Zn and NPK nano-fertilizers on seed yield and morphological traits in chickpea under rainfed condition. Journal of Resources and Ecology 4:221-228. http://ecologyresearch.info/documents/EC0091.pdf

Eichert T, Kurtz A, Steiner U, Goldbach HE (2008). Size exclusion limits and lateral heterogeneity of the stomatal foliar uptake pathway for aqueous solutes and water-suspended nanoparticles. Physiologia Plantarum 134(1):151-160. https://doi.org/10.1111/j.1399-3054.2008.01135.x

Feizi H, Moghaddam PR, Shahtahmassebi N, Fotovat A (2013). Assessment of concentrations of nano and bulk iron oxide particles on early growth of wheat (Triticum aestivum L.). Annual Research and Review in Biology 3(4):752-761. https://journalarrb.com/index.php/ARRB/article/view/24882

Fernández V, Eichert T, Del Río V, López-Casado G, Heredia-Guerrero JA, Abadía A, ... Abadía J (2008). Leaf structural changes associated with iron deficiency chlorosis in field-grown pear and peach: physiological implications. Plant and Soil 311(1):161-172. https://doi.org/10.1007/s11104-008-9667-4

Fernández V, Sotiropoulos T, Brown P (2015). Fertilización foliar. Principios científicos y prácticas de campo. Asociación Internacional de la Industria de Fertilizantes (IFA). Paris, Francia. pp 49-82.

Ghafari H, Razmjoo J (2013). Effect of foliar application of nano-iron oxidase, iron chelate and iron sulphate rates on yield and quality of wheat. International Journal of Agronomy and Plant Production 4(11):2997-3003. http://www.ijappjournal.com/wp-conten

Hageman RH, Hucklesby DP (1971). Nitrate reductase from higher plants. Methods in Enzymology 23:491-503. https://doi.org/10.1016/S0076-6879(71)23121-9

Kandpal ND, Sah N, Loshali R, Joshi R, Prasad J (2014). Co-precipitation method of synthesis and characterization of iron oxide nanoparticles. Journal of Scientific and Industrial Research 73:87-90. http://nopr.niscair.res.in/handle/123456789/26444

Kanwar MK, Sun S, Chu X, Zhou J (2019). Impacts of metal and metal oxide nanoparticles on plant growth and productivity. In: Husen A, Iqbal M (Eds). Nanomaterials and Plant Potential. Springer, Cham. https://doi.org/10.1007/978-3-030-05569-1_15

Karacan MS, Aslantaş N (2008). Simultaneous preconcentration and removal of iron, chromium, nickel with N, N'etylenebis-(ethane sulfonamide) ligand on activated carbon in aqueous solution and determination by ICP-OES. Journal of Hazardous Materials 155(3):551-557. https://doi.org/10.1016/j.jhazmat.2007.11.107

Liu R, Lal R (2015). Potentials of engineered nanoparticles as fertilizers for increasing agronomic productions. Science of the Total Environment 514:131-139.

Mahajan R, Zargar SM, Aezum AM, Farhat S, Gani M, Agrawal GK, Rakwal R (2015). Evaluation of iron, zinc, and protein contents of common bean (Phaseolus vulgaris L.) genotypes: a collection from Jammu \& Kashmir, India. Legume Genomics and Genetics 6(2):1-7. https://doi.org/10.5376/lgg.2015.06.0002

Mohammad GH, Malakouti MJ, Dadpour MR, Stroeve P, Mahmoudi M (2013). Effects of magnetite nanoparticles on soybean chlorophyll. Environmental Science and Technology 47(18):10645-10652. https://doi.org/10.1021/es402249b 
Nasiri Y, Zehtab-Salmasi S, Nasrullahzadeh S, Najafi N, Ghassemi-Golezani K (2010). Effects of foliar application of micronutrients ( $\mathrm{Fe}$ and $\mathrm{Zn}$ ) on flower yield and essential oil of chamomile (Matricaria chamomilla L.). Journal of Medicinal Plants Research 4(17):1733-1737. https://doi.org/10.5897/JMPR10.083

Panwar J, Jain N, Bhargaya A, Akhtar M, Yun Y (2012). Positive effect of zinc oxide nanoparticles on tomato plants: a step towards developing nano-fertilizers. In: International Conference on Environmental Research and Technology (ICERT), Malaysia.

Ravet K, Touraine B, Boucherez J, Briat JF, Gaymard F, Cellier F (2009). Ferritins control interaction between iron homeostasis and oxidative stress in Arabidopsis. The Plant Journal 57(3):400-412. https://doi.org/10.1111/j.1365-313X.2008.03698.x

Rawat M, Nayan R, Negi B, Zaidi MGH, Arora S (2017). Physio-biochemical basis of iron-sulfide nanoparticle induced growth and seed yield enhancement in B. juncea. Plant Physiology and Biochemistry 118:274-284. https://doi.org/10.1016/j.plaphy.2017.06.021

Rui M, Ma C, Hao Y, Guo J, Rui Y, Tang X, ... Zhu S (2016). Iron oxide nanoparticles as a potential iron fertilizer for peanut (Arachis hypogaea). Frontiers in Plant Science 7: 815. https://doi.org/10.3389/fpls.2016.00815

Rui M, Ma C, White JC, Hao Y, Wang Y, Tang X, ... Xing B (2018). Metal oxide nanoparticles alter peanut (Arachis hypogaea L.) physiological response and reduce nutritional quality: a life cycle study. Environmental Science: Nano 5(9):2088-2102. https://doi.org/10.1039/C8EN00436F

Sánchez E, Rivero RM, Ruiz JM, Romero L (2004). Changes in biomass, enzymatic activity and protein concentration in roots and leaves of green bean plants (Phaseolus vulgaris $L$. cv. Strike) under high $\mathrm{NH}_{4} \mathrm{NO}_{3}$ application rates. Scientia Horticulturae 99(3-4):237-248. https://doi.org/10.1016/S0304-4238(03)00114-6

Sánchez E, Soto JM, Ruiz JM, Romero L (2006). Asimilación de nitrógeno en raíces y hojas de frijol ejotero: deficiencia vs toxicidad de nitrógeno [Nitrogen assimilation in green bean roots and leaves: nitrogen deficiency vs toxicity]. Revista Fitotecnia Mexicana 29(3):187-195.

Servin AD, White JC (2016). Nanotechnology in agriculture: next steps for understanding engineered nanoparticle exposure and risk. NanoImpact 1:9-12. https://doi.org/10.1016/j.impact.2015.12.002

Sharma P, Jha AB, Dubey RS, Pessarakli M (2012). Reactive oxygen species, oxidative damage, and antioxidative defense mechanism in plants under stressful conditions. Journal of Botany 2012:217037. https://doi.org/10.1155/2012/217037

Sheykhbaglou R, Sedghi M, Shishevan MT, Sharifi RS (2010). Effects of nano-iron oxide particles on agronomic traits of soybean. Notulae Scientia Biologicae 2(2):112-113. https://doi.org/10.15835/nsb224667

Sida-Arreola JP, Sánchez-Chávez E, Ávila-Quezada GD, Zamudio-Flores PB, Acosta MC (2015). Iron biofortification and its impact on antioxidant system, yield and biomass in common bean. Plant, Soil and Environment 61(12):573-576. https://doi.org/10.17221/643/2015-PSE

Siddiqui MH, Al-Whaibi MH, Firoz M, Al-Khaishany MY (2015) Role of Nanoparticles in Plants. In: Siddiqui M, AlWhaibi M, Mohammad F (Eds). Nanotechnology and Plant Sciences. Springer, Cham. https://doi.org/10.1007/978-3-319-14502-0_2

Solanki P, Bhargava A, Chhipa H, Jain N, Panwar J (2015). Nano-fertilizers and their smart delivery system. In: Nanotechnologies in Food and Agriculture. Springer, Cham., pp 88-101. https://doi.org/10.1007/978-3319-14024-7_4

Suárez-Martínez SE, Ferriz-Martínez RA, Campos-Vega R, Elton-Puente JE, de la Torre Carbot K, García-Gasca T (2016). Bean seeds: leading nutraceutical source for human health. CyTA-Journal of Food 14(1):131-137. https://doi.org/10.1080/19476337.2015.1063548

Szarka A, Tomasskovics B, Bánhegyi G (2012). The ascorbate-glutathione- $\alpha$-tocopherol triad in abiotic stress response. International Journal of Molecular Sciences 13(4):4458-4483. https://doi.org/10.3390/ijms13044458

Van Hoewyk D, Abdel-Ghany SE, Cohu CM, Herbert SK, Kugrens P, Pilon M, Pilon-Smits EA (2007). Chloroplast ironsulfur cluster protein maturation requires the essential cysteine desulfurase CpNifS. Proceedings of the National Academy of Sciences 104(13):5686-5691. https://doi.org/10.1073/pnas.0700774104

Wang Y, Hu J, Dai Z, Li J, Huang J (2016). In vitro assessment of physiological changes of watermelon (Citrullus lanatus) upon iron oxide nanoparticles exposure. Plant Physiology and Biochemistry 108:353-360. https://doi.org/10.1016/j.plaphy.2016.08.003

Wellburn AR (1994). The spectral determination of chlorophylls a and b, as well as total carotenoids, using various solvents with spectrophotometers of different resolution. Journal of Plant Physiology 144(3):307-313. https://doi.org/10.1016/S0176-1617(11)81192-2 
Yaneva IA, Baydanova VD, Vunkova-Radeva RV (2000). Nitrate reductase activation state in leaves of molybdenumdeficient winter wheat. Journal of Plant Physiology 157(5):495-501. https://doi.org/10.1016/S01761617(00)80104-2

Ye L, Li L, Wang L, Wang S, Li S, Du J, ... Shou H (2015). MPK3/MPK6 are involved in iron deficiency-induced ethylene production in Arabidopsis. Frontiers in Plant Science 6: 953. https://doi.org/10.3389/fpls.2015.00953

Yemm EW, Cocking EC, Ricketts RE (1955). The determination of amino-acids with ninhydrin. Analyst 80(948):209214. https://doi.org/10.1039/AN9558000209

Zhang Y, Dai B, Deng Y, Zhao Y (2016). In vitro anti-inflammatory and antioxidant activities and protein quality of high hydrostatic pressure treated squids (Todarodes pacificus). Food Chemistry 203:258-266. https://doi.org/10.1016/j.foodchem.2016.02.072

Zia-ur-Rehman M, Naeem A, Khalid H, Rizwan M, Ali S, Azhar M (2018). Responses of plants to iron oxide nanoparticles. In: Nanomaterials in Plants, Algae, and Microorganisms. Academic Press, pp 221-238. https://doi.org/10.1016/B978-0-12-811487-2.00010-4

OPEN ACCESS

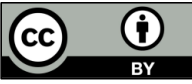

The journal offers free, immediate, and unrestricted access to peer-reviewed research and scholarly work. Users are allowed to read, download, copy, distribute, print, search, or link to the full texts of the articles, or use them for any other lawful purpose, without asking prior permission from the publisher or the author.

License - Articles published in Notulae Botanicae Horti Agrobotanici Cluj-Napoca are Open-Access, distributed under the terms and conditions of the Creative Commons Attribution (CC BY 4.0) License.

(C) Articles by the authors; UASVM, Cluj-Napoca, Romania. The journal allows the author(s) to hold the copyright/to retain publishing rights without restriction. 